EVIDENCE FOR HOPE 


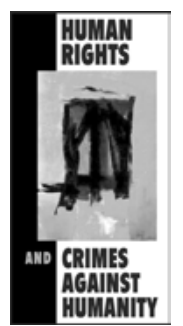

Human Rights and Crimes against Humanity

ERIC D. WEITZ, SERIES EDITOR

A list of titles in this series appears at the back of the book. 


\title{
Evidence for Hope
}

\section{MAKING HUMAN RIGHTS WORK \\ IN THE 21ST CENTURY}

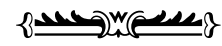

Kathryn Sikkink 
Copyright (C) 2017 by Princeton University Press

Published by Princeton University Press,

41 William Street, Princeton, New Jersey 08540

In the United Kingdom: Princeton University Press,

6 Oxford Street, Woodstock, Oxfordshire OX2o 1TR

press.princeton.edu

Jacket design by Jennifer Heuer

All Rights Reserved

ISBN 978-o-691-17062-6

Library of Congress Control Number: 2017941736

British Library Cataloging-in-Publication Data is available

This book has been composed in Miller

Printed on acid-free paper. $\infty$

Printed in the United States of America

$109876 \begin{array}{llllll} & 9 & 4 & 3 & 2 & 1\end{array}$ 
To the memory of Albert O. Hirschman and to my lifelong mentors/friends, all of whom modeled different ways to be a committed and rigorous scholar:

Raymond Duvall, Elizabeth Jelin, Robert Keohane, John Ruggie, and David Weissbrodt 
